\title{
SOCIAL INNOVATION: CHARACTERISTICS RELATED TO SUSTAINABLE DEVELOPMENT
}

\section{INOVAÇÃO SOCIAL: CARACTERÍSTICAS RELACIONADAS AO DESENVOLVIMENTO SUSTENTÁVEL}

\section{Y. D. S. FIGUEIREDO ${ }^{1, *}$, M. A. PRIM ${ }^{2}$ and G. A. DANDOLINI ${ }^{3}$}

${ }^{1}$ Federal University of Santa Catarina, Department of Engineering and Knowledge Management, Florianópolis, Santa Catarina, Brazil

${ }^{2}$ Federal University of Santa Catarina, Department of Engineering and Knowledge Management, Florianópolis, Santa Catarina, Brazil

${ }^{3}$ Institute of Santa Catarina, Department of Engineering and Knowledge Management, Florianópolis, Santa Catarina, Brazil

${ }^{*}$ Corresponding author. Federal University of of Santa Catarina, Department of Engineering and Knowledge Management, Florianópolis, Santa Catarina, Brazil, Phone: $+55489.9968-6556$

e-mail addressl: yohanidominik@gmail.com (Y.D.S. Figueiredo).

\begin{tabular}{l} 
A R T I C L E I N F O \\
\hline Article history: \\
Received 2020-07-21 \\
Accepted 2020-09-04 \\
Available online 2020-09-04 \\
p a l a vra $s-c h$ a ve \\
Inovação Social \\
Desenvolvimento Sustentável \\
Objetivos de Desenvolvimento \\
Sustentável \\
$k$ e y w o r $d s$ \\
Social Innovation \\
Sustainable Development \\
Sustainable Development Goals
\end{tabular}

\begin{abstract}
A B S T R A C T
Social innovation and sustainable development are topics of research interest for political leaders and civil society players, as well as for scholars from different disciplinary fields. They are presented as an effective, efficient, and sustainable solution to social problems generated by the present. In this sense, this research aims to identify characteristics of social innovation that are associated with sustainable development, from a narrative review of the literature. As a result, it was possible to identify characteristics such as improving quality of life and wellbeing, social change, innovative nature, among others, which are directly linked to the constructs of sustainable development. Special attention should be paid to the Sustainable Development Goals, which go hand in hand with social innovation actions as a way to reverse the situation of environmental degradation and social indigence.
\end{abstract}

R E S U M O

A inovação social e o desenvolvimento sustentável são temas interesse de investigação para os governantes politicos e os atores da sociedade civil, bem como para os estudiosos de diversos campos disciplinares. Apresentam-se como uma solução eficaz, eficiente e sustentável para os problemas social, gerados pela atualidade. Neste sentido, esta pesquisa tem como objetivo identificar características da inovação social que se associam com o desenvolvimento sustentável a partir de uma revisão narrativa da literatura. Como resultado, foi possivel identificar características como melhoria na qualidade de vida e bem-estar, mudança social, natureza inovadora, entre outras que estão diretamente ligadas com os construtos do desenvolvimento sustentável. Destaca-se especial atenção para os Objetivos de Desenvolvimento Sustentável, que caminha lado a lado com ações de inovações sociais, como forma de inverter o quadro de degradação ambiental e miséria social. 


\section{INTRODUCTION}

Social innovation (SI) is a topic of great research interest for political leaders and civil society players, as well as for scholars from different disciplinary fields (CAJAIBASANTANA, 2014; TERSTRIEP; TOTTERDILL, 2014), due to the its potentiality to produce new solutions to the multiple challenges and problems that communities and societies face (HILLIER; MOULAERT; NUSSBAUMER, 2004; TERSTRIEP; TOTTERDILL, 2014).

In this context, there is a need for alternatives with a look towards society, contemplating the solution of these social problems, with new paradigms that work with themes such as: social inclusion, environmental sustainability, new forms of work and income, valorization of the human being, and people's quality of life. This new thinking must be aligned with local development and economic growth, in order to provide social change and better opportunities for citizens, allowing them to be independent and autonomous (ANDRÉ; ABREU, 2006; BIGNETTI, 2011; CAJAIBA-SANTANA, 2014).

In parallel, the wide dissemination of the concept of sustainable development (SD) is also focused on the purpose of facing social crises (PERIAC; DAVID; ROBERSON, 2018). In this sense, in 2015 the United Nations Organization (UN) brought together 150 world leaders from 193 countries to develop a collective action plan, with the purpose of putting the world on a more sustainable and resilient path by 2030. It was then created the 2030 Agenda, which is a table of results, which presents the 17 Sustainable Development Goals (SDGs) and its 169 targets (AGENDA 2030, 2018).

Sustainable development plays an important role in creating long-term benefits. For Ionescu (2015), people have always been concerned with improving their living conditions, with social and economic progress. They aim at a better and foreseeable future with opportunities to achieve their goals; however they must safeguard that right to the future generations. This concept becomes the basis of quality of life and well-being, and is considered one of the pillars of sustainable development (OGANISJANA; SURIKOVA, 2015).

The social context is one of the perspectives currently addressed by sustainable development, in addition to the economic and environmental vision; however, it was not always so (WICHAISRI; SOPADANG, 2018). Firstly, sustainable development was approached from an economic perspective and, in a second step, the environmental bias gained visibility, and only from 2011 the three dimensions (economic, social, and environmental) have been treated with the same intensity. While economic aspects are related to organizational performance, social aspects are treated as part of the environmental impact (WICHAISRI; SOPADANG, 2018).

As presented above, the depth and importance of sustainable development can be seen, in line with the concept of social innovation, from their interrelation in the social perspective. Both concepts aim to achieve better quality of life and well-being for the community and both aspire to economic progress in view of a promising future.
In this sense, this research seeks to answer the following question: What characteristics of Social Innovation are associated with Sustainable Development? Therefore, the objective of this study is to identify characteristics of Social Innovation that are associated with Sustainable Development, contributing to a systemic view regarding these constructs, in order to enable the understanding of factors that make the concepts related.

This article presents the results and conclusions of that discussion and is organized in the following sections: firstly, this Introduction; in a second chapter, the theoretical framework composed of the sections: the Issue of Social Innovation; and Sustainable Development; in the third chapter, the Methodology. The fourth chapter deals with the Discussion and the fifth with the Final Considerations.

\section{THE ISSUE OF SOCIAL INNOVATION}

Currently, in order to embark on the study on this theme, any researcher has to go through a large number of articles with multiple definitions and various means of analysis and distinct and different aspects of social innovation (PACHECO; SANTOS; SILVA, 2018). Therefore, this section aims to present a contextualization, concepts, and particularities of the SI, to understand the discussion about its characteristics that are associated with the SD.

After the period in which innovation was a portrait of the technological domain, the idea of social innovation gains more and more space, and appears in several areas (ANDRÉ; ABREU, 2006). In the last two decades, the term has advanced rapidly in terms of visibility and attracts the interest of researchers, professionals and policy makers worldwide (EDWARDS-SCHACHTER; MATTI; ALCÁNTARA, 2012). This popularity is due to major social challenges that have arisen today, such as climate change, the global epidemic of chronic diseases, and social inequalities (hunger, education, health and poverty), which the existing structures and policies have not endured (MULGAN, 2006; MURRAY; CAULIER-GRICE; MULGAN, 2010).

In this scenario, several social movements focused their attention on these challenges and the need to promote sustainable development (MICHEL; HUNDON, 2015). In this perspective, social innovation proves to be an effective, efficient, and sustainable solution to a social problem, with the purpose of generating greater social value than existing practices, and its benefits reach the whole of society (PHILLS; DEIGMEIER; MILLER, 2008), and it helps to reduce disparities.

Understanding that the concept of social innovation has proliferated substantially in recent years, it is noted that this growth came associated with very heterogeneous fields of knowledge (management, design, psychology, economics, sociology, etc.), in addition to being associated with several others terms (social entrepreneurship, third sector, social capital, ecology, corporate social responsibility, etc.) making it difficult to understand its universe of meanings (PACHECO; SANTOS; SILVA, 2018). 
With this in mind, Pacheco, Santos, and Silva (2018) used the fields of knowledge on social innovation already proposed by Moulaert (2010; 2016) and Jessop et al., (2013), which are management and economics sciences, arts and creativity, political sciences and participatory public management, and local development, and mapped the most influential authors for each field mentioned. The perspective presented by these authors made it possible to elect the authors used in this research, in order to recognize the characteristics of Social Innovation.

In the field of arts and creativity, Mumford (2002), the most influential researcher on the subject, expanded his knowledge about the dynamics of creative processes, in order to highlight the unique character of the innovations produced in the contexts of social systems and from social interactions. The research by Mumford and Moertl (2003), on the other hand, emphasizes the role of leadership, creativity, and collaboration, and emphasizes that social innovation emerges as a timeconsuming process, involving continuous improvements, adjustments, and varied interactions of different players.

The areas of Management and Economics appear with greater force in the works by Mulgan (2006) and Mulgan et al., (2007), this author being the most influential in the category. His emphasis is on conceptual clarification and defining the factors that distinguish social innovation from technological innovation, which is fundamentally motivated by the maximization of profits. From works related to this category, it is clear that social innovation is seen as a means of transforming markets and reaching more inclusive levels of development and interactions (PACHECO; SANTOS; SILVA, 2018).

The dimension of political sciences and participatory public management were grouped with studies of territorial development, due to the difficulty of unlinking them, and the most relevant research from this perspective is the one by Moulaert $(2010,2016)$. This field focuses on the analysis of the administrative political system, with an emphasis on the proposal for change (territorial decentralization, greater transparency, accountability, attribution of power and control by the players involved), and also includes studies related to local development. Within this line of research, the researches by Moulaert (2005) and Moulaert et al. (2007) prove to be the more relevant.

Finally, Pacheco, Santos, and Silva (2018) add to their research two more fields of knowledge on social innovation, which depict the studies on social entrepreneurship and psychology. While studies on social entrepreneurship have acquired relevance, the field of psychology results only from occasional initiatives to promote studies on SI. However, these two areas of knowledge added to the study by Pacheco, Santos, and Silva (2018) are not relevant to this research, as they do not directly address characteristics regarding Social Innovation.

Taking into account the authors identified as most relevant in the mentioned contexts (management and economics sciences, arts and creativity, political sciences and participatory public management, and local development), the present work goes on to describe the definitions defended by the authors in question, making it possible to clarify them and provide the identification of existing consensus regarding the fundamental characteristics of the concepts.

Starting with the most relevant author in the area of knowledge called arts and creativity, Mumford (2002), who conceptualizes social innovation as the generation and application of new ideas about how people should organize interpersonal or social interaction activities to meet one or more common objectives, which may vary with respect to their scope and impact.

As for the area of management and economics, the most powerful researchers are Mulgan et al. (2007). They think the concept of social innovation refers to new ideas that work to achieve social goals: innovative activities and services that are motivated by the objective of meeting a social need and that are predominantly developed and disseminated through organizations whose main objectives are social.

Finally, Moulaert et al., (2007), who present social innovation as a tool for an alternative vision of urban development, focused on meeting human needs (and empowerment) through innovation in relationships within the neighborhood and the community governance, stand out in the dimension of political sciences, participatory public management, and territorial development.

In view of the concepts presented, there is some consensus in certain aspects, such as an emphasis on their innovative nature, in the specific contexts of social problems, in order to obtain better living conditions for the community and better relationships, interpersonal or with organizations, for social benefit.

Identified such concepts and characteristics of social innovation, this work assumes that SIs have characteristics that are associated with sustainable development, so that socially innovative initiatives can be guidelines for promoting SD (CORREIA et al., 2018). From the analysis of the selected articles, the main characteristics of social innovation are recognized: a) improvement in the people's quality of life and well-being; b) assistance for social needs; c) partnerships; d) social inclusion; e) community capacitation; f) social change; g) transforming social relations, and $\mathrm{h}$ ) innovative nature.

Thus, after the characterization of social innovation, the next section will address sustainable development, the second basic concept necessary to constitute this research.

\section{SUSTAINABLE DEVELOPMENT}

During the past decades, several social movements have turned their attention to the challenges of globalization and the need to promote development in a sustainable way (MICHEL; HUNDON, 2015). The concern created by the challenges of globalization is mainly directed to the ideology that economic growth is the main stream of development (SEYFANG; LONGHURST, 2013), often treated as its synonym. This behavior results in an increase in social disparities, a deterioration of local economies (TRACEY; ANNE, 2008), and a depletion of natural resources, causing degradation of the environment (JACKSON, 2009).

In this perspective, a new global development model is considered, with the adjective sustainable, which takes into account environmental and social spheres in addition to the economic bias. This new model is called Sustainable Development. The main issue about the idea of SD is related to breaking the paradigm of unilateral development, that is, the development that concentrates actions only from an economic 
perspective, to endogenous development, which occurs from the insertion of the community into democratic practices capable of enhancing the population's well-being and living conditions and generating an increase in its income, in addition to preserving and improving the environmental conditions of its surroundings (CORREIA et al., 2018).

With this scenario in mind, a chronological perspective of the concept in question will be briefly presented. A series of events raised the need for a new development model, where concerns were not only focused on the economic perspective, but also on considering environmental and social issues. At the heart of these discussions were initially environmental disasters, which motivated several nations to a global debate about the current development model and its real consequences for humanity.

In 1973, the first conference aimed at environmental discussions took place. Thus, the concept of eco-development emerged and was later developed and presented as ñsustainable developmentò in the Brundtland Report, in 1987. This report resulted from the World Commission on Environment and Development (DIAS, 2006). The World Commission on Environment Development understands SD as meeting present needs, without compromising the future generations (WCED, 1987).

Realizing that a large proportion of the world's population still lived in poverty, that there were serious disparities between resource use patterns of rich and poor countries, and that global ecosystems were already suffering from acute stress, that document suggested an international consensus to reorient the economic activities, in order to privilege the urgent development needs of the poor and avoid irreversible damage to the global environment (MEADOWCROFT, 2000). After the presentation of the concept of sustainable development in the Brundtland Report, there was rapid adherence by national governments, as well as by a large group of international organizations.

However, as expected, an idea that was deliberately formulated to function as a new pattern for global conduct, sustainable development has been the subject of a variety of criticisms. Many environmentalists have criticized their "anthropocentrism" and deplore the fact that this concept shamelessly promotes human well-being as a central value. They argue that, instead of being concerned with maintaining development, one should be more concerned with maintaining the natural environment (MEADOWCROFT, 2000).

On the other hand, critics of "development" have argued that sustainable development is little more than a crude attempt to try to maintain economic hegemony between countries by establishing measures of resource use. Within the social sciences, the focus turned to arguments related to its definition, identifying logical inconsistencies in the idea. Many commentators criticized the ambiguities associated with sustainable development. Some have suggested that the term is so empty that it could be invoked to justify any policy and it should be noted that sustainable development was not formulated to be a logical construction or an operational maxim, but as a goal, a potentially unifying political objective, with a suggestive normative nucleus (MEADOWCROFT, 2000).

Despite the criticisms, there has been a great proliferation of definitions on the SD theme, and the terms ñsustainableò and ñsustainabilityò are attributed together with a wide range of expressions. Although there are a variety of concepts, there has been a small evolution regarding the dominant understanding and, in recent years, it is a common fact to treat it as a joint assessment of economic, social, and environmental scenarios (MEADOWCROFT, 2000).

In 2005, Hopwood, Mellor and O'Brien mapped out different approaches to SD. They noted that all of these approaches continue to address environmental and socioeconomic perspectives, but each one seeks to solve sustainability problems centered on different objectives (more environmental, or more socioeconomic, or both), and with different contexts.

The literature used to carry out this research was based on authors referenced in the works of Lélé (1991), Baroni (1992), and Bolis, Moriola, and Sznelwar (2014). There may be some strangeness in the use of a review of concepts dated almost 30 years ago; however, the works of Lélé (1991) and Baroni (1992) bring concepts of SD that are still referenced today, as seen in the work of Bolis, Moriola and Sznelwar (2014), for example.

Barbier (1987) works with the idea that sustainable development aims to reduce the absolute poverty in the world and to provide safe and permanent livelihoods that minimize resource depletion, environmental degradation, disruption of culture and social instability.

Still in the same year, Goodland (1987) defines SD as a pattern of economic and social transformations, which optimizes benefits available in the present, without destroying the future potential, to achieve a reasonable and equitably distributed level of economic well-being. It also implies using renewable resources in a way that does not degrade or eliminate them or diminish their usefulness for future generations.

Finally, bringing a little more recent references, Axelsson et al. (2011) treat sustainable development as a collective social process that involves several stakeholders with different skills and level of salience. Olawumi and Chan (2018) adopted the concept of sustainable development in their review work as being multidimensional, integrated, and based on the principles of sustainability.

Having presented the brief contextualization, evolution, and conceptualization of sustainable development, it is possible to note that despite the variety of concepts, their characteristics permeate common points, such as social vulnerability, economic viability, and environmental sustainability.

At the current juncture, it is impossible to talk about sustainable development without talking about global agreements. Nowadays, the 2030 Agenda is the current agreement, being a guide for the actions of the international community in the coming years. It is considered an action plan, which was collectively created to put the world on a more sustainable and resilient path by 2030 .

The 2030 Agenda concerns the objectives of sustainable development and comprises 17 goals, namely: 1) eradication of poverty; 2) zero hunger and sustainable agriculture; 3) good health and well-being; 4) quality education; 5) gender equality; 6) clean water and sanitation; 7) affordable and clean energy; 8) decent work and economic growth; 9) industry, innovation and infrastructure; 10) reduced of inequalities; 11) sustainable cities 
and communities; 12) responsible consumption and production; 13) action against global climate change; 14) life below water; 15) life on land; 16) peace, justice and effective institutions, and finally 17) partnerships and means of implementation of the goals.

These goals are integrated and indivisible and mix, in a balanced way, the three dimensions of sustainable development: economic, social, and environmental. They work as a list of tasks to be performed by governments, civil society, the private sector, and all citizens on the collective journey towards a sustainable 2030 .

In the coming years of implementing the 2030 Agenda, the SDGs and their targets will stimulate and support actions in areas of crucial importance to humanity: People, Planet, Prosperity, Peace, and Partnerships (PLATAFORMA AGENDA 2030, 2018).

The next section will address the methodological procedures adopted for the discussion regarding the characteristics of Social Innovation that are associated with Sustainable Development, making it possible to understand the path and relevance of the research.

\section{METHODOLOGY}

This section presents the methodological procedures adopted for this research. It is a qualitative research, carried out through a narrative review of the literature, which has the purpose of describing and discussing the ñstate of the artò about a subject, from a theoretical or contextual perspective and expanding the knowledge base in the research area (SMITH, 2012). For this purpose, it was sought the literature published in books and articles in printed and/or electronic magazines, with interpretation and personal critical analysis by the author (ROTHER, 2007). This group of articles constitutes the corpus of this research and it is what allows the researcher to acquire and update knowledge on a given theme in a more agile way.

Although the narrative review does not require criteria for the selection of documents, for the present study it was decided to follow some steps in order to achieve a better delimitation and alignment of the articles. After defining the constructs to be researched, a search was carried out in the Scopus and WoS databases using the descriptors ñsocial innovationò AND ñsustainable developmentò. The period of issue of the documents was not defined. The option ñtitle, abstract and keywordsò was used in the Scopus research field, and ñtopicsò in the WoS. 161 and 74 documents were found respectively.

However, when reading the abstracts, it was found that the documents had little alignment with the research question or were applied in a very specific context. In this situation, it was decided to restrict the type of search to ñArticle Titleò in order to find works that deal directly with the two study objects in question, in search of a systemic view on the subject, and to be able to understand the relationships that associate the characteristics of SI with SD from the observation of the elements that make up these concepts.

Therefore, after excluding duplicates, non-adherents and not made available, the portfolio of work that comprises the discussion section was formed by five articles. In addition, one article was included manually from a directed research.
Presented the methodology, the next section explains the discussion regarding the selected articles.

\section{DISCUSSION}

Having exposed the theoretical framework that substantiated the understanding of the basic concepts dealt with in this study, this section aims to present the discussion related to the research question: ñWhat characteristics of Social Innovation are associated with Sustainable Development?ò.

The studied documents present different objectives and varied research scenarios. However, all of them deal directly with SI and SD, being possible to list the characteristics taken into consideration by their authors. Within this context, it was possible to carry out an analysis of characteristics of social innovation that are considered adherent to sustainable development, and, primarily, correlate them with the SDGs.

After the analysis of the articles chosen for this investigation, it was observed that the concepts of SI have a consensus in the vast majority, since everyone understands SI as a new alternative for solving social problems. From the analysis of the articles, the following characteristics of social innovation are recognized: a) improvement in the people's quality of life and well-being; b) assistance to social needs; c) partnerships; d) social inclusion; e) community capacitation; f) social change; g) transformation of social relations, and $h$ ) innovative nature.

As for the concepts of $\mathrm{SD}$, it is noted that the articles mostly work with the concept presented in the Brundtland Report. It is concluded that the SD is characterized by a change of priorities on the part of society, with the incorporation of a new ethics centered on the pursuit of collective interests, and of its structure of production and consumption, as a way to reverse the environmental degradation and social indigence that result from economic growth (ARAÚJO; CANDIDO, 2015).

The researchers herein start from the assumption that the characteristics of the SI and the concept of SD have a direct relationship, as they work in the 17 SDGs. It should be noted that the SDGs are integrated and indivisible actions, and that they blend, in a balanced way, in three dimensions: economic, social, and environmental. They become an unprecedented global commitment to eradicate poverty, improve people's quality of life, ensure environmental sustainability, provide inclusive and equitable opportunities for quality education for all, building sustainable partnerships and so on (MITITELU et al., 2016), in line with the characteristics of Social Innovation.

Therefore, the SI perspective can help to overcome the disconnection between economic growth and social well-being, promoting sustainable development (CORREIA et. al., 2018). It is an effective, efficient, and sustainable solution to a social problem, generating greater value than the existing practices, and its benefits reaching the whole society (PHILLS; DEIGMEIER; MILLER, 2018; MITITEL; FIORANI; LITARD, 2016).

Having explained in general terms the relationship between the two constructs, it is concluded that the SI characteristics have a strong alignment with the SDGs proposals, making it possible to draw relationships between them:

ÅThe improvement in quality of life and well-being can be associated with practically all SDGs, except directly with 
goals $12,13,14,15$, and 17 .

AMeeting social needs does not only apply directly to goals $9,13,14,15$, and 17 .

Partnerships and innovative nature are directly associated with all SDGs.

ASocial inclusion is not directly promoted only by goals $12,13,14,15$, and 17.

ÁCommunity capacitation may not be achieved directly by goals $3,5,7,9,13,16$, and 17 . and 10 .

A Social change can be achieved directly by goals 5,8 ,

Åransformations in social relationships can happen directly through goals $4,5,8,11$, and 17

Thus, it is concluded that the SI perspective can help to overcome the disconnection between economic growth and social well-being, being a stimulus to sustainable development (CORREIA et al., 2018). It presents itself as an effective, efficient and sustainable solution to a social problem, generating greater value than the existing practices, and its benefits reaching the entire society.

\section{FINAL CONSIDERATIONS}

This research sought, through a narrative review of the literature, to identify characteristics of SI that are associated with SD. First, the research presented a brief introduction, in order to contextualize the problem to be investigated. In a second step, the theoretical framework was presented, in order to promote understanding about the concepts related to SI and SD.

Based on the concepts presented, the researchers conclude that the SI and the SD are constructs that talk to each other, so that the development of SI actions is not likely without the systemic thinking of the SD. In addition to this issue, we assume that the SDGs are objectives created for the purpose of maintaining and even improving the future of generations, as they have among their goals care with economic, social, and environmental issues.

Together with the SDGs, SI deals with the creation of a transformative reality, based on new possibilities and new opportunities for a portion of the population that for various reasons is excluded.

It should also be noted that both constructs are the focus of studies by different political and academic institutions and communities in general. The search for socially positive changes, focused on the transformation of social relationships and sustainable development, constitutes a break in the paradigms of growth focused only on the economy. This change is absolutely necessary for the development of humanity in the item People, Planet, Prosperity, Peace, and Partnerships, described as essential by the 2030 Agenda.

Finally, the research allows continuity of study on the topic, leaving the suggestion to understand how the relation of each element of the SI occurs in relation to the SDGs, by researching in depth their performance. One can also analyze how public policies could align with socially innovative initiatives in favor of sustainable development.
A C K N O W LE D G M E N T

This work was carried out with the support of the Coordination for the Improvement of Higher Education Personnel - Brazil (CAPES) - Financing Code 001.

R E FER E N CES

ANDRÉ, Isabel; ABREU, Alexandre. Dimensões e espaços da inovação social. Finisterra, v. 41, n. 81, 2006.

ARAÚJO, Rudrigo Otávio Andrade; CÂNDIDO, Gesinaldo Ataíde. Tecnologia social e inovação social: interação indutora do desenvolvimento sustentável nos territórios rurais. Revista ESPACIOS, Vol. 36 ( $\mathrm{N}^{\circ}$ 13) Año 2015, 2015.

AXELSSON, Robert et al. Sustainable development and sustainability: Landscape approach as a practical interpretation of principles and implementation concepts. Journal of Landscape Ecology, v. 4, n. 3, p. 5-30, 2011.

BARBIER, Edward B. The concept of sustainable economic development. Environmental conservation, v. 14, n. 2, p. 101-110, 1987.

BARONI, Margaret. Ambigüidades e deficiências do conceito de desenvolvimento sustentável. Revista de Administração de Empresas, v. 32, n. 2, p. 14-24, 1992.

BIGNETTI, Luiz Paulo. As inovações sociais: uma incursão por ideias, tendências e focos de pesquisa. Ciências Sociais Unisinos, v. 47, n. 1, p. 3-14, 2011.

BOLIS, Ivan; MORIOKA, Sandra N.; SZNELWAR, Laerte I. When sustainable development risks losing its meaning. Delimiting the concept with a comprehensive literature review and a conceptual model. Journal of Cleaner Production, v. 83, p. 7-20, 2014.

CAJAIBA-SANTANA, Giovany. Social innovation: Moving the field forward. A conceptual framework. Technological Forecasting and Social Change, v. 82, p. 42-51, 2014.

CORREIA, Suzanne Nóbrega et al. Inovação Social para o Desenvolvimento Sustentável: um caminho possível. Administração Pública e Gestão Social, p. 199-212, 2018.

DIAS, T. L. P. Os peixes, a pesca e os pescadores da Reserva de Desenvolvimento Sustentável Ponta do Tubarão. 2003. Tese de Doutorado. Macau-Guamaré/RN, Brasil. 2006.

HILLIER, Jean; MOULAERT, Frank; NUSSBAUMER, Jacques. Trois essais sur le rôle de l'innovation sociale dans le développement territorial. Géographie, économie, société, v. 6, n. 2, p. 129-152, 2004.

HOPWOOD, Bill; MELLOR, Mary; O'BRIEN, Geoff. Sustainable development: mapping different approaches. Sustainable development, v. 13, n. 1, p. 38-52, 2005.

IONESCU, Cornel et al. About the conceptualization of social innovation. Theoretical and Applied Economics, v. 22, n. 3, p. 53-62, 2015.

JACKSON, Tim. Prosperity without growth: Economics for a finite planet. Routledge, 2009.

JESSOP, Bob et al. Social innovation research: a new stage in innovation analysis. The international handbook on social innovation: Collective action, social learning and transdisciplinary research, p. 110-130, 2013.

LÉLÉ, Sharachchandra M. Sustainable development: a critical 
review. World development, v. 19, n. 6, p. 607-621, 1991.

MEADOWCROFT, James. Sustainable development: a new (ish) idea for a new century?. Political studies, v. 48, n. 2, p. $370-387,2000$.

MICHEL, Arnaud; HUDON, Marek. Community currencies and sustainable development: A systematic review. Ecological economics, v. 116, p. 160-171, 2015.

MILLARD, Jeremy et al. Social innovation for poverty reduction and sustainable development: some governance and policy perspectives. In: Proceedings of the 9th International Conference on Theory and Practice of Electronic Governance. ACM, 2016. p. 153-162.

MILLARD, Jeremy et al. Social innovation for poverty reduction and sustainable development: some governance and policy perspectives. In: Proceedings of the 9th International Conference on Theory and Practice of Electronic Governance. ACM, 2016. p. 153-162.

MITITELU, Cristina; FIORANI, Gloria; LITARDI, Irene. Fostering sustainable development, entrepreneurship, and social innovation through CSR: the new role of university. Opportunities and Risks in the Contemporary Business Environment, p. 951, 2016.

MOULAERT, Frank et al. Introduction: social innovation and governance in European cities: urban development between path dependency and radical innovation. 2007.

MOULAERT, Frank et al. Towards alternative model (s) of local innovation. Urban studies, v. 42, n. 11, p. 19691990, 2005.

MOULAERT, Frank. Social innovation and community development: concepts, theories and challenges. In: Can Neighbourhoods Save the City?. Routledge, 2010. p. 2032.

MOULAERT, Frank. Social innovation: Institutionally embedded, territorially (re) produced. In: Social innovation and territorial development. Routledge, 2016. p. $27-40$.

MULGAN, Geoff et al. Social innovation: what it is, why it matters and how it can be accelerated. 2007.

MULGAN, Geoff. The process of social innovation. Innovations: technology, governance, globalization, v. 1, n. 2, p. 145-162, 2006.

MUMFORD, Michael D. Social innovation: ten cases from Benjamin Franklin. Creativity research journal, v. 14, n. 2, p. 253-266, 2002.

MUMFORD, Michael D.; MOERTL, Peter. Cases of social innovation: Lessons from two innovations in the 20th century. Creativity Research Journal, v. 15, n. 2-3, p. 261-266, 2003.

MURRAY, Robin; CAULIER-GRICE, Julie; MULGAN, Geoff. The open book of social innovation. London: National endowment for science, technology and the art, 2010.

OGANISJANA, Karine; SURIKOVA, Svetlana. Social innovation in the promotion of sustainable development of the contemporary Latvian society. Journal of Security \& Sustainability Issues, v. 5, n. 2, 2015.

OLAWUMI, Timothy O.; CHAN, Daniel WM. A scientometric review of global research on sustainability and sustainable development. Journal of cleaner production, 2018.

PACHECO, Anderson Sasaki Vasques; SANTOS, Maria João; SILVA, Karin Vieira Da. Social innovation: what do we know and do not know about it. International Journal of Innovation and Learning, v. 24, n. 3, p. 301-326, 2018.

PERIAC, Fabrice; DAVID, Albert; ROBERSON, Quinetta. Clarifying the interplay between social innovation and sustainable development: A conceptual framework rooted in paradox management. European Management Review, v. 15, n. 1, p. 19-35, 2018.

PHILLS, J.; DEIGLMEIER, K.; MILLER, T. Rediscovering Social Innovation: Stanford Social Innovation Review. 2008.

PLATAFORMA AGENDA 2030. Acelerando as transformações para a Agenda 2030 no Brasil. Available at: <http://www.agenda2030.org.br/>. Accessed on September 15, 2018.

ROTHER, Edna Terezinha. Revisão sistemática $X$ revisão narrativa. Acta paulista de enfermagem, v. 20, n. 2, p. vvi, 2007.

SEYFANG, Gill; LONGHURST, Noel. Desperately seeking niches: Grassroots innovations and niche development in the community currency field. Global Environmental Change, v. 23, n. 5, p. 881-891, 2013.

SMITH, Alison M. Research methodology: A step-by-step guide for beginners. Nurse Education in Practice, v. 12, n. 3, p. e25, 2012.

TERSTRIEP, Judith; TOTTERDILL, Peter. Economic foundation of social innovation: New modes of policy production. In: RIP 2014ï 9th Regional Innovation Policies Conference. 2014.

TRACEY, Strange; ANNE, Bayley. OECD Insights. Sustainable Development: Linking economy, society, environment. OECD Publishing, 2008.

WCED, 1987. Relatório da Comissão Mundial sobre Meio Ambiente e Desenvolvimento - Nosso Futuro Comum, acrônimos e nota sobre terminologia. Oxford University Press, Oxford.

WICHAISRI, Sooksiri; SOPADANG, Apichat. Trends and Future Directions in Sustainable Development. Sustainable Development, v. 26, n. 1, p. 1-17, 2018. 